\title{
Kejahatan Dunia Maya Pada Sektor Perbankan Di Indonesia: Analisa Perlindungan Hukum Terhadap Nasabah
}

\author{
Kukuh Dwi Kurniawan,* Dwi Ratna Indri Hapsari \\ Fakultas Hukum Universitas Muhammadiyah Malang, Indonesia \\ *Email Correspondensi: kukuhdwik@gmail.com \\ No. Handphone Correspondensi: (+62) 81259360006
}

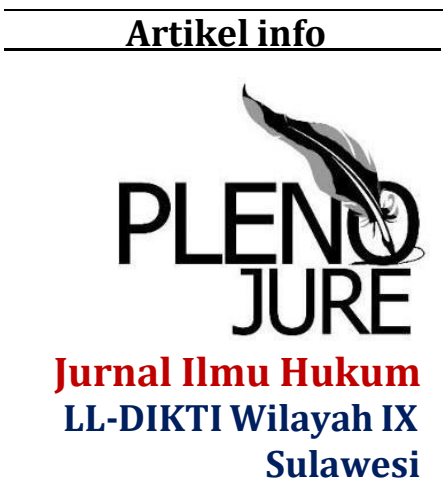

Artikel history:
Received; 24-08-2021
Revised: 27-10-2011
Accepted: 30-10-2011
Abstrak. Perkembangan teknologi elektronik sejalan dengan semakin meningkatnya kejahatan, dari kejahatan secara konvensional menjadi kejahatan yang memanfaatkan keahlian dibidang teknologi elektronik untuk kepentingan sendiri atau orang lain. Penelitian ini untuk menelaah lebih mendalam mengenai perlindungan hukum kepada konsumen sektor perbankan atas suatu bentuk kejahatan cyber di Indonesia. Jenis kejahatan dunia maya pada sektor perbankan diantaranya adalah skimming, malware dan hacking. Seringnya kejahatan tersebut merugikan pihak bank dan nasabah secara finansial. Bentuk perlindungan hukum bagi nasabah atas kejahatan dunia maya telah diatur melalui UUPK, UU Perbankan, UU ITE, UU Telekomunikasi serta secara teknis termuat dalam Peraturan Otoritas Jasa Keuangan. Penelitian menggunakan pendekatan yuridis yang mendeskripsikan regulasi terkait perlindungan nasabah bank atas kejahatan tindak pidana cybercrime. Dari hasil penelitian ini menunjukkan secara preventif regulasi dalam hukum positif saat ini memberikan kewajiban kepada bank sebagai badan usaha untuk selalu menjaga dan melindungi nasabah dari kejahatan dunia maya. Secara represif apabila nasabah mengalami kerugian finansial atas kejahatan dunia maya maka Langkah yang dapat dilakukan adalah dengan jalan non-litigasi dan litigasi.

Abstract. The development of electronic technology is in line with the increasing number of crimes, from conventional crimes to crimes that use expertise in the field of electronic technology for their own or other people's interests. This study aims to examine more deeply the legal protection for consumers in the banking sector for a form of cybercrime in Indonesia. Types of cybercrime in the banking sector include skimming, malware and hacking. Often these crimes harm the bank and customers financially. Forms of legal protection for customers against cybercrimes have been regulated through the UUPK, the Banking Law, the ITE Law, the Telecommunications Law and are technically contained in the Financial Services Authority (OJK) Regulations. The study uses a juridical approach that describes regulations related to the protection of bank customers against cybercrime crimes. The results of this study indicate that preventively, regulations in 


\begin{tabular}{l} 
Keywords: \\
Cybercrime; \\
banking; \\
Customers; \\
Protection. \\
\hline
\end{tabular}

positive law currently provide an obligation to banks as business entities to always maintain and protect customers from cybercrimes. Repressively, if customers experience financial losses due to cybercrimes, the steps that can be taken are non-litigation and litigation.

artikel dengan akses terbuka dibawah lisensi CC BY-SA 4.0

\section{PENDAHULUAN}

Peradaban manusia telah menuju pada era teknologi informasi yang menjadi tumpuan penting dalam aktivitas manusia. Ketergantungan terhadap pemanfaatan teknologi pada hampir semua kegiatan manusia sudah menjadi makanan sehari-hari. Sektor perbankan kemudian menjadi salah satu sektor yang mau tidak mau harus pula mengikuti pesatnya teknologi informasi berkembang. Hampir dalam seluruh penyelenggaraan sistem pembayaran yang terjadi di Indonesia dilakukan secara elektronik atau paperless. Para pelaku usaha kemudian dalam tanda kutip dipaksa mengikuti arus berkembagnya tekologi informasi dengan menyesuaikan dengan iklim ekonomi moderen. Mulai dari merubah strategi bisnis dan model platform dari offline menjadi online dengan pemanfaatan teknologi informasi yang berperan penting dalam terobosan produk dan jasa. Pelayanan sistem pembayaran secara elektronik merubah model transaksi secara manual menjadi electronic transaction.

Namun demikian, perkembangan teknologi elektronik sejalan dengan semakin meningkatnya kejahatan, dari kejahatan secara konvensional menjadi kejahatan yang memanfaatkan keahlian dibidang teknologi informasi untuk kepentingan diri sendiri dan/atau orang lain (Aswari, 2018). Pada prinsipnya kejahatan yang memanfaatkan teknologi informasi dapat dikategorikan sebagai white collar crime, sebagaimana ciri dari pelaku white collar crime adalah mereka yang memanfaatkan kepandaiaan dan/atau skill dalam melakukan kejahatan sehingga pelaku sendiri tidak merasa dirinya menjadi korban dari tindak kejahatan. Perbuatan yang dilakukan dengan memanfaatkan perangkat komputer dan jaringan internet untuk melakukan manipulasi data sedemikian rupa dengan tujuan mendapatkan keuntungan secara melawan hukum.

Asosiasi Penyelenggara Jasa Internet Indonesia (APJII) merilis data bahwa hasil penelusuran Pengguna Internet Indonesia pada tahun 2019-2020 adalah sebesar 73,7 persen, naik dari 64,8 persen dari tahun 2018. Apabila digabungkan dengan angka dari proyeksi Badan Pusat Statistik (BPS) maka populasi Indonesia tahun 2019 berjumlah 266.911 .900 juta, sehingga pengguna internet Indonesia diperkirakan sebanyak 196,7 juta pengguna (APJII, 2020).

Pejabat Bank Indonesia menjelaskan dalam laporan Financial Services Information Sharing and Analysis Center, menjelaskan bahwa Indonesia menjadi negara kesembilan dari sepuluh (10) negara yang memiliki angka suseptibel tinggi akan kejahatan cyber (Lidyana, 2020). Saat kondisi pandemi Covid-19 ini ancaman kejahatan dunia maya semakin meningkat, semisal 
terjadi pada awal pandemic terjadi panic buying atas masker dan hand sanitizer. Hal tersebut oleh beberapa oknum yang dimanfaatkan guna meraup keuntungan pada kondisi darurat secara tidak bertanggung jawab (Qodar, 2020).

Masih pada tahun yang sama, pelaku kejahatan cyber menargetkan salah satu marketplace besar di Indonesia. Tepatnya pada bulan maret 2020, data user Tokopedia dicuri dan diduga pelaku peretas berasal dari Pakistan (Mukaromah, 2020). Informasi peretasan tersebut bermula dari diketahuinya ada pihak yang menjual di dark web seharga US\$ 5.000 atau sekitar 74 Juta berupa 91 juta catatan Tokopedia (Aldin, 2020). Dan yang terbaru pada tahun 2021, sejumlah 279 juta data WNI telah diretas dan dijual pada Raid Forums, dari data tersebut yang diretas berupa nama, alamat, nomor telepon serta besaran gaji (Hikam, 2021).

Cakupan kejahatan cyber begitu luas dan semakin hari semakin bermunculan bentuk - bentuk baru dengan menggunakan peralatan komputer, jaringan komputer, serta jenis-jenis kejahatan yang dulu sifatnya tradisional kemudian mulai berkembang menjadi kejahatan cyber dengan atau tanpa peralatan komputer. Dari adanya kejahatan cyber ini menjadikan perbankan, merchant, marketplace, toko online atau nasabah sebagai korban oleh pihakpihak yang tidak bertanggung jawab memanfaatkan teknologi informasi sehingga korban tersebut mengalami kerugian finansial.

PBI Nomor 9/15/PBI/2007 tentang Penerapan Manajemen Risiko Dalam Penggunaan Teknologi Informasi Oleh Bank Umum, memberikan definisi "layanan perbankan melalui media elektronik atau selanjutnya disebut Electronic Banking adalah layanan yang memungkinkan nasabah bank untuk memperoleh informasi, melakukan komunikasi, dan melakukan transaksi perbankan melalui media elektronik antara lain ATM, phone banking, electronic fund transfer, internet banking, mobile phone" (Penerapan Manajemen Risiko Dalam Penggunaan Teknologi Informasi Oleh Bank Umum, 2007).

Kejahatan maya ditemukan berbagai bentuk dan selalu berkembang. Pada sektor perbankan, layanan perbankan melalui media elektronik diantaranya adalah skimming, malware serta hacking dengan memanfaatkan akses internet pada saat melakukan transaksi yang kemudian dimanfaatkan oleh pelaku kejahatan cyber tersebut (Faridi, 2018). Informasi perbankan serta layanan transaksi perbankan sangat dimungkinkan menggunakan layanan Electronic Banking (E-banking) oleh bank sehingga nasabah dapat dengan mudah melakukan berbagai macam transaksi perbankan dengan memanfaatkan jaringan internet. Misalnya melakukan pengecekan saldo simpanan, pembayaran beberapa tagihan, pembelian, transfer dana baik sesama bank maupun antar bank, pembukaan rekening baru, serta transaksi perbankan yang lain (Indonesia \& Perbankan, 2014). Perubahan strategi bisnis perbankan bagi pelaku usaha sebagai suatu terobosan baru pemanfaatan teknologi informasi dalam pengembangan produk-produk sektor perbankan. Apalagi sektor perbankan di Indonesia memegang peranan yang sangat penting dalam pertumbuhan perekonomian negara, pemerataan serta stabilitas ekonomi bangsa atau yang kerap disebut sebagai Agent of Development (Disemadi \& Prananingtyas, 2019).

Pemanfaatan teknologi informasi pada sektor perbankan menjadi hal 
yang sangat krusial untuk mempermudah transaksi. Namun demikian, hal tersebut dibarengi juga dengan risiko kejahatan dunia maya yang memanfaatkan situasi lemahnya bank dan nasabah sebagai korban yang dapat mengalami kerugian secara finansial. Penelitian ini menjadi penting karena nasabah menempati posisi yang lebih lemah dibandingkan dengan pihak bank. Sehingga perlindungan terhadap nasabah atas kejahatan dunia maya menjadi sangat penting untuk dikaji lebih lanjut. Penelitian ini ingin mengerti lebih mendalam mengenai sejauh mana perlindungan hukum terhadap nasabah atas kejahatan dunia maya pada sektor perbankan di Indonesia?

\section{METODE}

Penelitian ini menganalisis terkait perlindungan hukum terhadap nasabah atas cybercrime pada sektor perbankan berdasarkan peraturan perundang-undangan yang berlaku di Indonesia. Memberikan deskripsi secara preskriptif atas permasalahan kejahatan cybercrime khususnya para nasabah dari perbankan, dengan menguraikan modus kejahatan dan tantangan dalam penegakan hukum cybercrime sendiri serta sejauh mana regulasi yang ada sekarang dapat memberikan jaminan perlindungan dalam upaya preventif dan represif sehingga dengan tujuan dapat menjadi payung hukum dlam penyelesaian kejahatan cyber pada sektor perbankan.

\section{HASIL DAN PEMBAHASAN}

Bank sebagai suatu badan usaha memiliki fungsi sebagai perantara keuangan (Financial Intermediary) yakni menerima dana (funding) dari masyarakat yang memiliki kelebihan dana dan menyalurkan kepada pengguna dalam bentuk kredit (Potabuga, 2019). Bank dan nasabah penyimpan dana memiliki ikatan yang dilandasi oleh trust atau kepercayaan, yang lazim disebut "fiduciary relation". Usaha perbankan tanpa adanya kepercayaan dari masyarakat sebagai nasabahnya maka dapat dipastikan tidak akan berjalan. Sehingga, wajib bagi bank untuk menjaga tingkat Kesehatan bank demi memberikan kepercayaan kepada masyarakat (Chalim, 2017).

Sebagaimana disebutkan di awal bahwa derasnya arus teknologi informasi mempengaruhi berbagai sektor kegiatan manusia salah satunya dalam bidang kegiatan perbankan. Pesatnya perkembangan teknologi informasi dengan tujuan untuk mempermudah kegiatan manusia. Efisiensi dan efektivitas menjadi poin yang sangat penting dalam kemajuan teknologi informasi dalam bidang perbankan. Inovasi pada produk dan jasa industri perbankan menjadi tidak terbendung lagi (Astrini, 2015). Namun demikian hal tersebut tetap harus sesuai dengan regulasi yang berlaku yakni Undang Undang Nomor 7 Tahun 1992 tentang Perbankan sebagaimana telah diubah dengan Undang-Undang Nomor 10 Tahun 1998 (UU Perbankan).

Bentuk efisiensi dari teknologi informasi pada sektor perbankan yang secara umum kita sebut Sebagai Elektronik Banking (E-banking), memberikan fasilitas layanan perbankan hanya dalam genggaman. Namun dibalik kemudahan-kemudahan tersebut terdapat risiko pemanfaatan data-data nasabah secara melawan hukum melalui kejahatan cyber. Sehingga badan usaha perbankan harus memiliki security features yang mumpuni agar dapat memberikan trust kepada masyarakat bahwa penggunaan teknologi informasi 
di bidang perbankan tetap dapat dilakukan. Pun juga demikian, instrumen hukum juga harus bisa memberikan rasa aman bagi nasabah sebagai konsumen dalam industri perbankan.

Kejahatan berkembang seiring dengan perkembangan teknologi informasi. Kejahatan yang berkelindan dengan teknologi informasi disebut sebagai cybercrime. Bentuk kejahatan tersebut yang telah lama diketahui adalah sebagai berikut (Kusuma, 2013):

a. menggunakan komputer tanpa izin,

b. memasuki sistem jaringan komputer secara melawan hukum,

c. manipulasi program dan/atau data computer,

d. pembocoran data,

e. kerusakan data pada komputer.

Tidak setiap orang memiliki kemampuan atau skill dalam melakukan jenis-jenis kejahatan cyber tersebut. Kejahatan cyber itu hanya dapat dilakukan oleh orang - orang yang memiliki pengetahuan serta skill tertentu. Hal tersebut merupakan harga yang harus dibayar sebagai suatu perubahan global masyarakat (global social changing) yang harus dibarengi dengan kemajuan hukum pula.

Semakin canggihnya suatu teknologi akan selalu berbanding lurus dengan revolusi kejahatan pada dunia maya. Sehingga akan selalu bermunculan jenis-jenis kejahatan baru yang mengikuti cybercrime tersebut. Bentuk perkembangan kejahatan cyber saat ini bermacam-macam seperti hacking, cracking, carding sampai probe, scan, account compromised, root compromise, denial of service, penyalahgunaan domain name serta bentuk - bentuk lain (Kusuma, 2013).

Metode yang sering digunakan oleh pelaku cybercrime pada sektor perbankan dengan memanfaatkan teknologi informasi diantaranya adalah (Faridi, 2018):

a. skimming, yakni suatu bentuk kejahatan cyber dengan cara mencuri informasi nasabah pada saat bertransaksi menggunakan Anjungan Tunai Mandiri (ATM);

b. malware (malicious software), yakni perangkat lunak berbahaya untuk mencuri data, merusak sistem serta perangkat komputer;

c. hacking, yakni suatu bentuk kejahatan cyber dengan cara penyerangan terhadap program komputer dan mengeksploitasi komputer milik orang pribadi atau perusahaan yang digunakan untuk kepentingan sendiri maupun orang lain secara melawan hukum.

Bentuk-bentuk kejahatan cyber tersebut jelas berpotensi merugikan secara finansial bagi nasabah. Oleh karenanya, menjadi suatu keharusan bahwa hukum melalui instrumen-instrumennya harus dapat melindungi nasabah yang menjadi korban dari cybercrime. Nasabah bank dalam hal ini berkedudukan sebagai konsumen dari badan usaha bidang perbankan dilindungi oleh hukum. Menurut Undang - Undang Nomor 8 Tahun 1999 tentang Perlindungan Konsumen (UUPK) pada Pasal 1 angka 1 menyebutkan bahwa "Perlindungan konsumen adalah segala upaya yang menjamin adanya kepastian hukum untuk memberi perlindungan kepada konsumen". Negara melalui berbagai sistem dan instrumen pelaksananya memberikan garansi dan kepastian hukum dengan memberikan perlindungan kepada konsumen di 
wilayah hukum Indonesia melalui upaya-upaya yang ditujukan untuk mencegah adanya ancaman pelaku usaha yang nakal atau tidak mau bertanggung jawab atas kegiatan usahanya tersebut. Adanya jaminan dari negara tersebut memberikan rasa aman bukan saja kepada para konsumen, namun juga kepada para pelaku usaha sehingga dapat tercipta iklim usaha yang sehat dengan tercipta nya kemudahan dalam memanfaatkan teknologi informasi pada aspek perbankan dengan baik sehingga tidak tercipta rasa takut atas tidak ada itikad baik dari para pelaku usaha dalam memberikan dan menjalankan kewajibannya atas hak yang harus diberikan kepada konsumen.

Landasan konstitusi bagi perlindungan hukum terhadap konsumen pun dapat merujuk pada Pasal 28D ayat (1) Undang - Undang Dasar 1945 yang menyatakan bahwa "Setiap orang berhak atas pengakuan, jaminan, perlindungan dan kepastian hukum yang adil serta perlakuan yang sama dihadapan hukum". Hal tersebutlah yang kemudian menjadikan dasar bahwa setiap orang memiliki hak untuk dilindungi secara hukum serta mendapatkan rasa aman. Nasabah dan pelaku usaha perbankan memiliki kedudukan yang sama dan seimbang berlandaskan asas:
a. manfaat;
b. keadilan;
c. keseimbangan;
d. keamanan;
e. keselamatan konsumen; serta,
f. kepastian hukum.

Dalam hal terdapat keluhan atas barang/jasa yang dikonsumsi maka hukum melalui UUPK memberikan jaminan bagi konsumen untuk dapat didengar pendapatnya. Dalam bidang perbankan nasabah sebagai konsumen jasa layanan perbankan juga dapat menyampaikan pendapat dan keluhan yang selama ini mungkin telah diakomodir melalui layanan customer service (CS) pada masing-masing bank. Namun demikian bank pun harus memiliki security system yang kuat serta terus melakukan inovasi dalam penanganan/mitigasi risiko teknologi yang dimiliki.

Guna mengimplementasikan ketentuan Pasal 29 dan Pasal 30 UUPK, Pemerintah telah menetapkan Peraturan Pemerintah Nomor 58 Tahun 2001 tentang Pembinaan dan Pengawasan Penyelenggaraan Perlindungan Konsumen. Ketentuan aturan tersebut mengatur terkait Pemerintah bertanggung jawab atas pembinaan penyelenggaraan perlindungan konsumen yang menjamin diperolehnya hak konsumen dan pelaku usaha serta dilaksanakannya kewajiban konsumen dan pelaku usaha serta pengawasan terhadap penyelenggaraan perlindungan konsumen dan penerapan ketentuan peraturan perundang-undangannya dilaksanakan oleh pemerintah, masyarakat, dan lembaga perlindungan konsumen swadaya masyarakat.

Guna mewujudkan perlindungan konsumen yang baik sebagaimana amanat UUPK, pemerintah mengesahkan Peraturan Pemerintah Nomor 57 Tahun 2007 dibentuk Badan Perlindungan Konsumen (BKN). BKN memiliki fungsi yang termuat pada Pasal 3 ayat (2) PP No 57 Tahun 2007, yakni:

a. "Memberikan saran dan rekomendasi kepada pemerintah dalam rangka penyusunan kebijaksanaan di bidang Perlindungan Konsumen; 
b. melakukan penelitian dan pengkajian terhadap peraturan perundang-undangan yang berlaku di bidang Perlindungan Konsumen;

c. melakukan penelitian terhadap barang dan/atau jasa yang menyangkut keselamatan Konsumen;

d. mendorong berkembangnya Lembaga Perlindungan Konsumen Swadaya Masyarakat (LPKSM);

e. menyebarluaskan informasi melalui media mengenai Perlindungan Konsumen dan memasyarakatkan sikap keberpihakan kepada Konsumen;

f. menerima pengaduan tentang Perlindungan Konsumen dari masyarakat, LPKSM, atau Pelaku Usaha; dan

g. melakukan survei yang menyangkut kebutuhan Konsumen.”

Dibentuknya Lembaga Perlindungan Konsumen Swadaya Masyarakat (LPKSM) sebagaimana perintah Pasal 44 UU UUPK. LPKSM dibentuk sesuai dengan amanah Peraturan Pemerintah Nomor 59 Tahun 2001 dan diubah melalui Peraturan Pemerintah Nomor 89 Tahun 2019. Adanya Lembaga ini diharapkan menjadi wadah kegiatan yang aktif melakukan perlindungan konsumen pada Tingkat Provinsi.

Pesatnya perkembangan di bidang teknologi informasi saat ini merupakan dampak dari semakin kompleksnya kebutuhan manusia akan informasi. Perkembangan teknologi informasi termasuk internet di dalamnya juga memberikan tantangan tersendiri bagi perkembangan hukum di Indonesia. Hukum di Indonesia dituntut untuk dapat menyesuaikan dengan perubahan sosial yang terjadi. Soekanto mengemukakan bahwa perubahan perubahan sosial dan perubahan hukum atau sebaliknya tidak selalu berlangsung bersama-sama. Artinya pada keadaan tertentu perkembangan hukum mungkin tertinggal oleh perkembangan unsur-unsur lainnya dari masyarakat serta kebudayaannya atau mungkin hal yang sebaliknya (Soekanto, 1986).

Perubahan selalu mendatangkan dampak positif dan negatif dan oleh karena itu para pelaku bisnis harus mampu beradaptasi dengan mengantisipasi dampak negatif tersebut secara mengantisipasi ancaman dan menjaga kepercayaan konsumen untuk memberikan kenyamanan konsumen dan perlindungan konsumen dalam bertransaksi (Setiawan et al., 2018). Perihal inilah yang menjadi tujuan dari para pelaku usaha bisnis secara online untuk dapat memberikan kenyamanan bertransaksi dan kepuasan atas produk online yang ditawarkan.

Upaya yang dilakukan pemerintah dalam rangka memberikan payung hukum ruang cyber dengan mengesahkan UU ITE pada tanggal 21 April 2008 dan telah mengalami perubahan menjadi Undang-Undang Nomor 19 Tahun 2016 tentang Informasi dan Transaksi Elektronik, yang memuat beberapa hal yakni; masalah yurisdiksi, perlindungan hak pribadi, asas perdagangan secara e-commerce, asas persaingan usaha usaha tidak sehat dan perlindungan konsumen, azas-azas hak atas kekayaan intelektual (HKI) dan hukum Internasional serta azas cybercrime.

Dalam rangka mewujudkan kemudahan serta keamanan dan kenyamanan dalam transaksi e-commerce. E-banking berusaha untuk 
melindungi penggunanya, dalam hal ini pelaku usaha dan konsumen yang memanfaatkan E-banking sebagai media pembayaran dari tindakan-tindakan yang dapat mengakibatkan kerugian. Pada dasarnya, media pembayaran $E$ banking menyediakan jasa transaksi pembelian barang dari konsumen kepada pelaku usaha. Kesepakatan mengenai harga serta detail - detail mengenai barang dan/atau jasa ditetapkan sendiri oleh pelaku usaha dan konsumen. Tanggung jawab pihak bank dalam e-banking adalah memastikan bahwa masing-masing pihak memiliki kemampuan dan kredibilitas sesuai kapasitasnya agar transaksi elektronik dapat berjalan lancar.

Pengaturan E-banking tentu saja tidak terlepas dari UU No 10 Tahun 1998 tentang perubahan atas UU No 7 Tahun 1992 tentang Perbankan Pasal 29 ayat (4) dan Pasal 40 tentang Rahasia Bank. Di Dalam peraturan hukum Positif, belum ada pengaturan yang khusus dan jelas mengenai e-banking. Namun UUITE, cukup mampu mengatur permasalahan-permasalahan hukum dari sistem Internet Banking sebagai salah satu layanan perbankan yang merupakan wujud perkembangan teknologi informasi sesuai dengan ketentuan Pasal 17 UU ITE. Adapun peraturan perundang-undangan yang dapat dikaitkan dengan e-banking adalah UU No 36 tahun 1999 tentang Telekomunikasi dalam Pasal 42 ayat (1) Menjelaskan bahwa penyelenggara jasa telekomunikasi wajib merahasiakan informasi dikirim atau diterima oleh pelanggan jasa telekomunikasi melalui jaringan telekomunikasi atau jasa telekomunikasi yang diselenggarakannya.

Secara lebih teknis, Otoritas Jasa Keuangan melalui Peraturan Otoritas Jasa Keuangan Nomor 1/POJK.07/2013 tentang Perlindungan Konsumen Sektor Jasa Keuangan, menegaskan "kewajiban Pelaku Usaha Jasa Keuangan menjaga keamanan simpanan, dana, atau asset konsumen yang berada dalam tanggung jawab Pelaku Usaha Jasa Keuangan" sebagaimana diatur dalam Pasal 25. Selanjutnya Pasal 29 pada POJK yang sama mengatur "Pelaku Usaha Jasa Keuangan wajib bertanggung jawab atas kerugian Konsumen yang timbul akibat kesalahan dan/atau kelalaian, pengurus, pegawai Pelaku Usaha Jasa Keuangan dan/atau pihak ketiga yang bekerja untuk kepentingan Pelaku Usaha Jasa Keuangan. Hal tersebut jelas memberikan perlindungan hukum terhadap nasabah" (Musrifah \& Sukananda, 2019).

Kemudian lebih lanjut lagi Pasal 23 Peraturan Otoritas Jasa Keuangan Nomor 38/POJK.03/2016 Tentang Penerapan Manajemen Risiko Dalam Penggunaan Teknologi Informasi Oleh Bank Umum menyebutkan bahwa:

(1) "Bank wajib menyelenggarakan Pemrosesan Transaksi Berbasis Teknologi Informasi di wilayah Indonesia.

(2) Pemrosesan Transaksi Berbasis Teknologi Informasi dapat dilakukan oleh pihak penyedia jasa di wilayah Indonesia.

(3) Penyelenggaraan Pemrosesan Transaksi Berbasis Teknologi Informasi oleh pihak penyedia jasa sebagaimana dimaksud pada ayat (2) dapat dilakukan sepanjang:

a. Memenuhi prinsip kehati-hatian;

b. Memenuhi persyaratan sebagaimana dimaksud dalam Pasal 20 ayat (3), ayat (4), dan ayat (5); dan

c. Memperhatikan aspek perlindungan kepada nasabah. 
(4) Pemrosesan Transaksi Berbasis Teknologi Informasi oleh pihak penyedia jasa Teknologi Informasi dapat dilakukan di luar wilayah Indonesia sepanjang:

a. Memenuhi persyaratan sebagaimana dimaksud pada ayat (3);

b. Dokumen pendukung administrasi keuangan atas transaksi yang dilakukan di kantor Bank di Indonesia wajib ditatausahakan di kantor Bank di Indonesia;

c. Rencana bisnis Bank menunjukkan adanya upaya untuk meningkatkan peran Bank bagi perkembangan perekonomian Indonesia; dan

d. Mendapatkan persetujuan terlebih dahulu oleh Otoritas Jasa Keuangan".

Masih diatur oleh POJK yang sama Pasal 29 mengatakan bahwa "Bank wajib menerapkan prinsip pengendalian pengamanan data nasabah dan transaksi Layanan Perbankan Elektronik pada setiap Sistem Elektronik yang digunakan oleh Bank". Ini menjadi kewajiban bagi para pelaku bisnis perbankan yang menjalankan usaha perbankkan secara online harus memberikan jaminan perlindungan mengenai data dan transaksi konsumen. Merujuk dari hasil penelitian yang dilakukan van de Weijer menunjukkan bahwa cybercrime merupakan jenis tingkat kejahatan yang paling sedikit dilaporkan dibandingkan dengan kejahatan konvensional (Weijer et al., 2018). Oleh karena itu diperlukan persiapan antipasti sebaik mungkin mengingat perbankan memiliki peran vital dalam roda perekonomian.

Ketika nasabah mengalami kerugian finansial dalam kegiatan perbankan yang dilakukan melalui e-banking maka berdasarkan aturan yang ada, sengketa dapat diselesaikan melalui litigasi atau non-litigasi sebagai alternatif penyelesaian sengketa. Apabila dalam penggunaan e-banking nasabah mengalami kerugian yang disebabkan oleh cybercrime maka nasabah dapat melakukan pelaporan/pengaduan atas apa yang dialami kepada pihak bank. Pelaporan/pengaduan tersebut kemudian akan diselesaikan oleh pihak bank karena hal itu menjadi suatu bentuk layanan peningkatan perlindungan terhadap hak-hak nasabah dalam hubungan hukumnya dengan bank. Penyelesaian pengaduan oleh nasabah kepada bank tersebut apabila tidak mendapat tanggapan yang baik dari pihak bank maka akan dapat menimbulkan citra dan reputasi yang buruk pada pihak bank sehingga kepercayaan masyarakat pada industri perbankan akan menurun. Penanganan terhadap pengaduan nasabah oleh setiap bank wajib membentuk unit yang memiliki fungsi penanganan aduan nasabah tersebut.

Penyelesaian sengketa antara badan usaha perbankan dengan nasabah sebagai konsumennya secara prosedur diatur dalam UUPK sebagai umbrella act, Keputusan Menteri Perindustrian dan Perdagangan Republik Indonesia Nomor 350/MPP/Kep/12/2001 tentang Pelaksanaan Tugas dan Wewenang Badan Penyelesaian Sengketa Konsumen, Peraturan Bank Indonesia Nomor 10/ 10 /PBI/2008 tentang Perubahan Atas Peraturan Bank Indonesia Nomor 7/7/PBI/2005 tentang Penyelesaian Pengaduan Nasabah dan Peraturan Otoritas Jasa Keuangan Nomor 1/POJK.07/2013 tentang Perlindungan Konsumen Sektor Jasa Keuangan. 


\section{SIMPULAN DAN SARAN}

Perkembangan teknologi informasi dalam sektor perbankan di satu sisi memberikan kemudahan bagi industri perbankan dan juga nasabah, pada sisi lain berpotensi munculnya risiko cybercrime yang dapat merugikan nasabah secara finansial. Industri perbankan sebagai suatu layanan jasa keuangan yang berlandaskan prinsip kepercayaan dari masyarakat maka harus tetap meningkatkan keamanan dari segi cyber security untuk selalu dapat mempertahankan kepercayaan masyarakat tersebut. Bentuk perlindungan hukum bagi nasabah atas kejahatan dunia maya telah diatur melalui UUPK, UU Perbankan, UUITE, UU Telekomunikasi serta secara teknis diatur dalam Peraturan Otoritas Jasa Keuangan. Secara preventif regulasi yang berlaku saat ini memberikan kewajiban kepada pelaku usaha jasa keuangan dalam hal ini pihak bank untuk selalu menjaga dan melindungi nasabah dari kejahatan dunia maya. Secara represif apabila nasabah mengalami kerugian finansial atas kejahatan dunia maya maka Langkah yang dapat dilakukan adalah dengan jalan non-litigasi dan litigasi. Oleh karena itu, sangat penting adanya regulasi yang secara tujuannya lebih mengarah kepada upaya preventif sehingga tidak lebih dahulu mendatangkan kerugian kepada konsumen, mengingat secara tingkat kerumitan penyelesaian dan pengungkapan suatu kejahatan dunia maya.

\section{DAFTAR RUJUKAN}

Aldin, I. U. (2020). Data Tokopedia Dikabarkan Diretas dan Dijual Seharga Rp 73 Juta. $\quad$ Katadata.Co.Id. https://katadata.co.id/ekarina/digital/5eae1fa9cfcc0/data-tokopediadikabarkan-diretas-dan-dijual-seharga-rp-73-juta

APJII. (2020). Asosiasi Penyelenggara Jasa Internet Indonesia. APJII. https://apjii.or.id/

Astrini, D. A. (2015). Perlindungan Hukum Terhadap Nasabah Bank Pengguna Internet Banking Dari Ancaman Cybercrime. Lex Privatum, 3(1), 149-160.

Aswari, A. (2018). Peran Ganda Administrator sebagai Mediator dalam Sengketa Transaksi Ponsel Bekas secara Online. Jurnal Ilmiah Kebijakan Hukum, 12(3), 259. https://doi.org/10.30641/kebijakan.2018.v12.259274

Penerapan Manajemen Risiko dalam Penggunaan Teknologi Informasi oleh Bank Umum, Pub. L. No. LEMBARAN NEGARA REPUBLIK INDONESIA TAHUN $2007 \quad$ NOMOR 144 DPNP, 32 (2007). https://peraturan.bpk.go.id/Home/Details/137629/peraturan-bi-no915 pbi2007

Chalim, F. (2017). Hubungan Hukum Antara Bank dan Nasabah Penyimpan Dana Menurut Undang-Undang Perbankan. Lex Et Societatis, 5(9), 120127. https://ejournal.unsrat.ac.id/index.php/lexetsocietatis/article/viewFile/ $18330 / 17858$

Disemadi, H. S., \& Prananingtyas, P. (2019). Perlindungan Hukum Terhadap Nasabah Perbankan Pengguna CRM (Cash Recycling Machine). Jurnal 
Magister Hukum Udayana (Udayana Master Law Journal), 8(3), 286. https://doi.org/10.24843/jmhu.2019.v08.i03.p07

Faridi, M. K. (2018). Kejahatan Siber dalam Bidang Perbankan. Cyber Security Dan Forensik Digital, 1(2), 57-61. https://doi.org/10.14421/csecurity.2018.1.2.1373

Hikam, H. A. Al. (2021). 3 Fakta Baru Dugaan Data BPJS Kesehatan Bocor, Ada yang Bikin Kaget! Detikfinance. https://finance.detik.com/beritaekonomi-bisnis/d-5582652/3-fakta-baru-dugaan-data-bpjs-kesehatanbocor-ada-yang-bikin-kaget

Indonesia, I. B., \& Perbankan, L. S. P. (2014). Mengelola Bank Komersial (1st ed.). PT.Gramedia Pustaka Utama. https://books.google.co.id/books?hl=id\&lr=\&id=qqBLDwAAQBAJ\&oi=fn $\mathrm{d} \& \mathrm{pg}=\mathrm{PP} 1 \& \mathrm{dq}=$ Ikatan+Bankir+Indonesia,+Mengelola+Bank+Komersial+ \&ots=ookyvaxHwM\&sig=8Zi-Qlng5_W27N4cwW2uBKNKsI\&redir_esc=y\#v=onepage\&q=Ikatan Bankir Indonesia\%2C Mengelola Bank Komersial\&f=fal

Kusuma, M. J. (2013). Perlindungan Hukum Terhadap Nasabah Bank Yang Menjadi Korban Kejahatan Ite Di Bidang Perbankan. Al' Adl, V(9), 32-55. https://doi.org/10.35796/les.v4i5.11962

Lidyana, V. (2020). Indonesia Masuk Daftar Negara Paling Rawan Cyber Crime. 2020. https://finance.detik.com/moneter/d-5248030/indonesia-masukdaftar-negara-paling-rawan-cyber-crime

Mukaromah, V. F. (2020). Tokopedia Diretas, Ini 3 Upaya Peretasan E-Commerce yang Pernah Terjadi. Kompas.Com - 03/05/2020. https://www.kompas.com/tren/read/2020/05/03/162700365/tokope dia-diretas-ini-3-upaya-peretasan-e-commerce-yang-pernahterjadi?page=all

Musrifah, R., \& Sukananda, S. (2019). ANALISIS PERLINDUNGAN HUKUM TERHADAP NASABAH DALAM TRANSAKSI E-BANKING DI INDONESIA Fakultas Hukum Universitas Muhammadiyah Yogyakarta ( UMY ) Yogyakarta Journal Diversi, Volume 4 , Nomor 1, April 2018 : 98-124 Saat ini dengan adanya fasilitas e-banking. Journal DIversi, 4(April 2018), 98124. https://doi.org/10.32503/diversi.v4i1.353

Potabuga, M. R. C. (2019). Perlindungan Hukum Terhadap Nasabah Bank. Lex Privatum, 6(10), 33-44. https://ejournal.unsrat.ac.id/index.php/lexprivatum/article/viewFile/2 $5843 / 25485$

Qodar, N. (2020). Virus Corona Picu Panic Buying Makanan, Masker, Hand Sanitizer, Bagaimana 2020. https://www.liputan6.com/news/read/4193886/headline-viruscorona-picu-panic-buying-makanan-masker-hand-sanitizer-bagaimanameredamnya

Setiawan, N., Emia Tarigan, V. C., Sari, P. B., Rossanty, Y., Putra Nasution, M. D. T., \& Siregar, I. (2018). Impact of cybercrime in e-business and trust. 
International Journal of Civil Engineering and Technology, 9(7), 652-656. https://www.researchgate.net/profile/Nashrudin-

Setiawan/publication/327335383_Impact_of_cybercrime_in_ebusiness_and_trust/links/60559c8f92851cd8ce52afe8/Impact-ofcybercrime-in-e-business-and-trust.pdf

Soekanto, S. (1986). Pengantar Penelitian Hukum. Penerbit Universitas Indonesia.

Weijer, S. G. A. van de, Leukfeldt, R., \& Bernasco, W. (2018). Determinants of reporting cybercrime: A comparison between identity theft, consumer fraud, and hacking. European Journal of Criminology, 16(4), 486-508. https://doi.org/10.1177/1477370818773610 